\title{
KARAKTERISTIK PATI GANYONG TERMODIFIKASI MELALUI IRADIASI UV-C (ULTRAVIOLET C) DAN HIDROLISIS ASAM LAKTAT
}

\author{
Visca Claudi Erezka, Iffah Muflihati, Enny Purwati Nurlaili, dan M. Khoiron Ferdiansyah \\ Program Studi Teknologi Pangan, Universitas PGRI Semarang \\ Email: viscaclaudierezka@gmail.com
}

\begin{abstract}
ABSTRAK
Pati merupakan bagian dari karbohidrat, sebagai salah satu sumber zat gizi penting bagi tubuh, Berbagai macam sumber pati, salah satunya yaitu umbi ganyong yang jarang dimanfaatkan, Pati ganyong perlu dimodifikasi agar dapat menghasilkan pati yang dibutuhkan di industri maupun oleh masyarakat, Salah satu modifikasi yang dapat diterapkan pada pati ganyong yaitu dengan iradiasi UV-C, Modifikasi dengan UV-C akan lebih optimal hasilnya jika dilakukan pada kondisi asam, Untuk dapat mencapai kondisi tersebut umumnya digunakan penambahan asam laktat, Penelitian ini bertujuan untuk mengetahui karakteristik pati ganyong yang dimodifikasi dengan iradiasi UV-C dan hidrolisis asam laktat, Formulasi yang digunakan yaitu lama penyinaran dengan lampu UV-C selama 5 menit, 10 menit, 15 menit, dan menggunakan konsentrasi asam laktat 0,5\%,1\%, 1,5\%, Rancangan yang digunakan yaitu metode faktorial dengan desain Rancangan Acak Lengkap (RAL), Hasil penelitian menunjukkan bahwa pati ganyong yang dimodifikasi menggunakan iradiasi UV-C dan hidrolisis asam laktat memiliki nilai swelling power yang menurun, nilai kelarutan meningkat, volume pengembangan meningkat, mengurangi tingkat kecerahan, meningkatkan tingkat kekuningan, serta menurunkan nilai $\mathrm{pH}$,

Kata kunci-asam laktat; kelarutan; lampu UV-C; swelling power; volume pengembangan
\end{abstract}

\section{PENDAHULUAN}

Pati merupakan salah satu sumber zat gizi yang penting bagi tubuh yang terdapat didalam makanan yang dikonsumsi setiap hari, Sebagian besar kebutuhan energi manusia dipenuhi dari karbohidrat yang dapat ditemukan pada biji-bijian dan umbi-umbian yang merupakan tempat penyimpanan pati untuk cadangan makanan bagi tanaman, Pati memiliki 2 komponen yaitu amilosa dan amilopektin (Pudjihastuti, 2010), Menurut Koswara (2009), pati memiliki peranan penting dalam industri pangan maupun non pangan, Dalam dunia perdagangan pati memiliki 2 jenis yaitu pati biasa dan pati yang telah dimodifikasi, Pati biasa yaitu semua jenis pati yang pada umumnya diproduksi oleh pabrik pengolahan dasar sedangkan pati modifikasi adalah pati yang memiliki hasil lebih baik dari pati biasa,

Umumnya pati berasal dari umbi, serealia, legum, batang, dan beberapa jenis buah tertentu seperti durian, Masyarakat lebih sering menggunakan pati yang berasal dari umbi-umbian karena bahan baku yang mudah didapatkan dan masyarakat sudah lebih mudah mendapatkan pati tersebut, Beberapa jenis umbi-umbian yang dikenal antara lain singkong, ubi jalar, kentang, garut, kimpul, gadung, gembili, dan ganyong, Umbi ganyong merupakan salah satu jenis umbi-umbian yang jarang dimanfaatkan, Umumnya umbi ganyong dikonsumsi masyarakat hanya dengan direbus atau dikukus saja, sangat jarang masyarakat memanfaatkan pati yang terdapat pada umbi ganyong tersebut, Pati ganyong merupakan pati yang berasal dari umbi ganyong dan dapat dimanfaatkan sebagai bahan pangan atau bahan untuk industri non pangan, Menurut Watcharatewinkul dkk (2008), pati ganyong memiliki kandungan amilosa yang tinggi (38\%), viskositas tinggi, dan mudah teretrogredasi, Pati asli seperti pati ganyong atau pati pada umumnya memiliki kelemahan seperti jika dimasak pati membutuhkan waktu yang cukup lama, pasta keras dan keruh, lengket, dan tidak tahan asam (Koswara, 2009),

Pada umumnya masyarakat dan industri membutuhkan pati yang memiliki kekentalan yang stabil dan tahan pada kondisi asam dan suhu tinggi, Sifat tersebut terdapat pada pati yang telah dimodifikasi, Menurut Pudjihastuti (2010), pati termodifikasi adalah pati yang telah berubah struktur molekulnya dengan cara kimia, fisik, maupun enzimatis, Pati modifikasi digunakan pada industri pangan dalam pembuatan salad krim, saus kental, mayonais, jeli, permen, coklat, dan lainnya, Sedangkan pada industri non pangan biasanya pati modifikasi ini digunakan pada industri tekstil, 
kertas, sabun, detergent, dan bahan bangunan, Ada beberapa cara yang digunakan untuk memodifikasi pati, seperti modifikasi dengan hidrolisis asam, enzim, ikat silang, dan oksidasi pati (Koswara, 2009), Semua cara modifikasi pati dapat menghasilkan sifat pati modifikasi yang berbedabeda,

Beberapa penelitian modifikasi pati yang telah dilakukan, seperti menggunakan hidrolisis asam laktat dan oksidasi $\mathrm{H}_{2} \mathrm{O}_{2}$ pada tapioka (Costa dkk,, 2012), Memodifiakasi tapioka menggunakan hidrolisis asam laktat daniradiasi lampu UV (mercury vapor lamp) (Bertolini dkk,, 2000), Selain itu modifikasi menggunakan Heat Moisture Treatment (HMT) pada pati ketan (Muflihati dkk, 2015) dan modifikasi HMTdan penambahan gum xanthan pada pati ganyong (Parwiyanti dkk, 2015), Modifikasi asetilasi dan cross-linking pada pati sagu (Teja dkk,, 2008), Modifikasi tapioka dengan oksidasi menggunakan sodium hipoklorit (Dias dkk, 2011 ), Modifikasi tapioka menggunakan iradiasi lampu UV Phillips 125W dan gamma (Bertolini dkk,, 2000),

Modifikasi dengan UV-C akan lebih optimal hasilnya jika dilakukan pada kondisi asam, Untuk dapat mencapai kondisi tersebut umumnya digunakan penambahan asam laktat, Modifikasi menggunakan hidrolisis asam laktat dan penyinaran UV-C dapat menghasilkan pati yang memiliki volume pengembangan meningkat dibanding pati alami, selain itu juga meningkatkan kelarutan pati didalam air, Penelitian yang pernah dilakukan oleh Setya (2015), menyatakan bahwa modifikasi tepung singkong menggunakan iradiasi UV-C selama 3 menit dan penambahan asam laktat 1\% dapat meningkatkan baking expansion tepung singkong, Selain itu terdapat penelitian lain yang dilakukan oleh Irawan dkk, (2013), memberikan hasil bahwa penggunaan asam laktat dan sinar UV untuk memodifikasi tepung tapioka dapat menurunkan tingkat viskositas tepung tapioka, Menurut Pudjihastuti (2010), yang telah melakukan penelitian modifikasi tapioka dengan penambahan asam laktat dan penyinaran UV menunjukkan bahwa nilai swelling power dan baking expansion meningkat sedangkan nilai viskositasnya menurun, Modifikasi pati singkong menggunakan penyinaran UV dan hidrolisis asam laktat menghasilkan nilai baking expansion dan viskositas yang mendekati terigu sehingga dapat untuk mengganti terigu (Sumardiono dan Pudjihastuti, 2015),

Penelitian yang banyak dilakukan untuk memodifikasi pati umumnya menggunakan pati singkong, jagung, dan kentang, Namun belum banyak penelitian yang memodifikasi pati ganyong melalui oksidasi UV-C dan hidrolisis asam laktat, Sehingga perlu dilakukan penelitian untuk mengetahui dampak atau pengaruh oksidasi menggunakan lampu UV-C dan hidrolisis asam laktat pada karakteristik pati ganyong,

\section{METODOLOGI PENELITIAN}

\section{A. Bahan dan Alat}

Bahan utama yang digunakan dalam modifikasi pati yaitu pati ganyong dengan merk dagang "Hasil Bumiku" yang diproduksi oleh "CV Kusuka Ubiku" Banguntapan Bantul Yogyakarta, Bahan lain yang digunakan adalah asam laktat $88 \%$ dan aquadest, Bahan yang digunakan dalam preparasi dan analisis sampel yaitu aquadest dan parafin,

Alat utama yang digunakan dalam modifikasi pati yaitu seperangkat lampu UV-C dan tumbler, Alat lain yang digunakan adalah beaker glass (IWAKI), pipet, timbangan analitik (SHIMADZU), botol spray, Sedangkan alat yang digunakandalam preparasi dan analisis sampel yaitu timbangan analitik (SHIMADZU), oven roti (Baker's Friend), oven (Memmert), desikator, pipet volume (IWAKI), gelas ukur (IWAKI), tabung sentrifuge (IWAKI), sentrifuge (Gemmy PLC-05), vortex(Lab Dancer), hot plate (IKA C-MAG), $\mathrm{pH}$ meter (Eutech USA type $\mathrm{pH} 5+$ ), dan chromameter,

\section{B. Rancangan Percobaan}

Penelitian ini menggunakan metode faktorial dengan desain RAL (Rancangan Acak Lengkap), Variabel bebas yaitu konsentrasi asam laktat $(0,5 \%, 1 \%$, dan $1,5 \%)$ dan lama penyinaran lampu UV-C setiap formula (5 menit, 10 menit, 15 menit), Variabel terikat yaitu uji kelarutan, swelling power, warna, volume pengembangan, dan $\mathrm{pH}$ ), 
Data hasil pengujian dianalisis dengan sidik ragam (Anova), Apabila hasil analisis tersebut menunjukkan berbeda nyata antara perlakuan, maka dilanjutkan dengan uji DMRT pada taraf 5\%, Analisis data dilakukan dengan menggunakan program SPSS 21,0,

\section{Analisis}

Analisis dilakukan terhadap 9 sampel pati ganyong termodifikasi, Kontrol yang digunakan adalah pati ganyong tanpa modifikasi, Analisis yang dilakukan pada penelitian ini yaitu kelarutan (Kainuma dkk,, 1967), swelling power (Kainuma dkk,, 1967), warna (Hutching 1999 dalam Lutfika, 2006), volume pengembangan (Demiate dkk,, 2000), dan pH (AOAC, 1990)

\section{HASIL DAN PEMBAHASAN}

\section{A. Swelling Power}

Modifikasi pati ganyong dengan hidrolisis asam laktat dan iradiasi UV-C dilakukan pada konsentrasi asam laktat $0,5 \% ; 1 \%$; dan 1,5\% dengan lama penyinaran menggunakan lampu UV-C 20 watt selama 5 menit, 10 menit, dan 15 menit, Kemudian pati terhidrolisis dikeringkan didalam cabinet dryer dengan suhu $\pm 50^{\circ} \mathrm{C}$ selama $1 \mathrm{jam}$, Masing-masing perlakukan kemudian dianalisis nilai swelling power, Untuk mengetahui nilaiswelling power dapat dilihat pada Gambar 1,

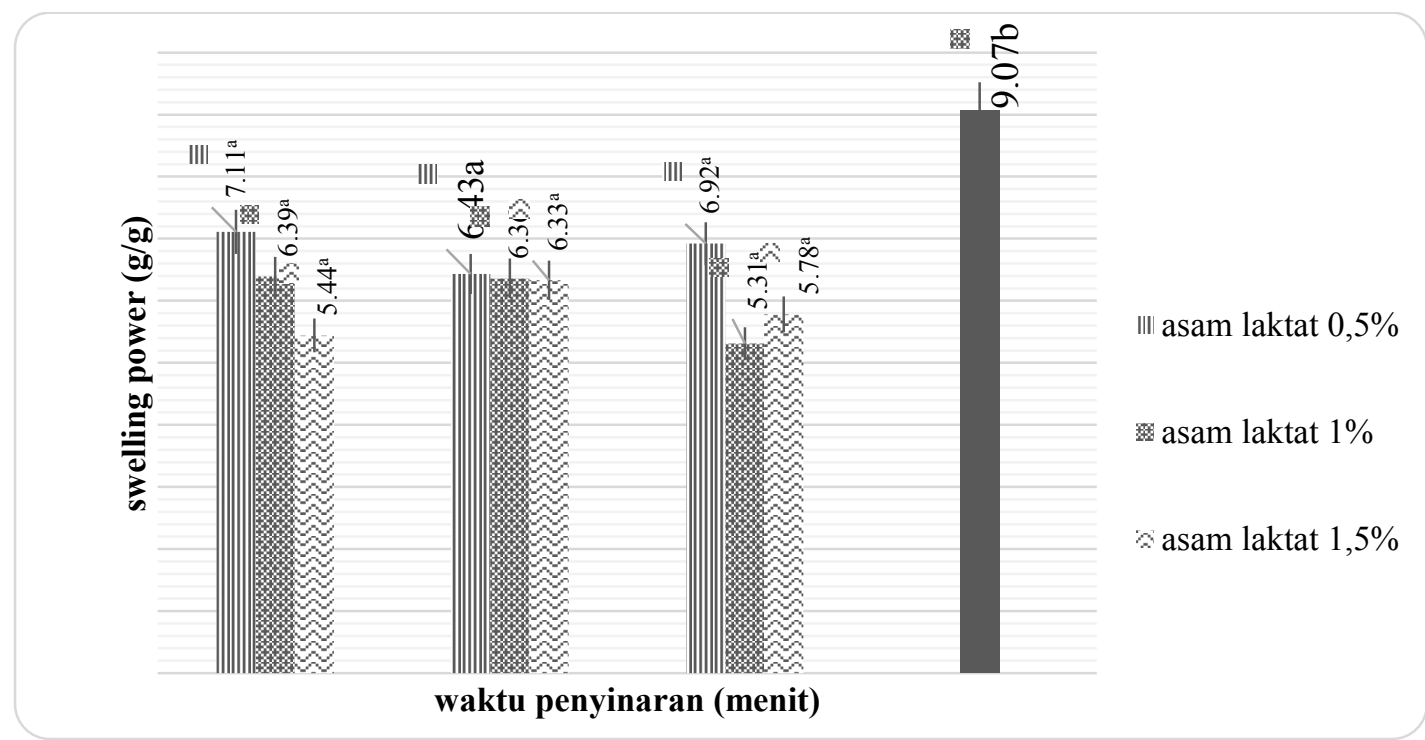

Gambar 1,Grafik Hasil Analisis Swelling Power

Hasil uji statistik pada analisis swelling power yang dapat dilihat pada Gambar 1, menunjukkan tidak berbeda nyata pada semua perlakuan, tetapi semua perlakuan menunjukkan hasil yang berbeda nyata dengan kontrol, Nilai swelling power pati ganyong termodifikasi lebih tinggi jika dibandingkan dengan kontrol, Hal ini karena gugus karbonil sangat berpengaruh pada degradasi amilosa, sehingga semakin meningkatnya degradasi amilosa maka pasta yang terbentuk akan semakin sedikit dan akan menurunkan nilai swelling power, Gugus karbonil adalah sebuah gugus fungsi yang terdiri dari sebuah atom karbon yang berikatan rangkap dengan sebuah atom oksigen, Pada penambahan asam laktat $1 \%$ nilai swelling power mengalami penurunan karena terdapat gugus amilosa yang terbentuk sehingga granula pati akan larut dalam air dan pasta yang terbentuk akan berkurang,

Sumardiono dan Pudjihastuti (2015) melakukan penelitian dengan modifikasi pati singkong menggunakan hidrolisis asam laktat dan UV menunjukkan semakin lama penyinaran lampu UV akan meningkatkan nilai swelling power sedangkan semakin bertambahnya konsentrasi asam laktat maka nilai swelling power semakin semakin lama juga waktu hidrolisis, yang menyebabkan rantai pati tereduksi dan menyebabkan rantai pati cenderung lebih pendek dan mudah menyerap air, 
Hasil yang berbeda ditunjukan oleh penelitian yang dilakukan oleh An (2005), dimana hasilnya menunjukkan bahwa granula pati yang menyerap air akan menyebabkan granula-granula pati membengkak dan berhimpitan sehingga nilai swelling power meningkat, Semakin lama hidrolisi maka akan menyebabkan amilosa tereduksi dan meningkatkan amilopektin, Amilopektin mempunyai sifat cenderung tidak larut dalam air, sehingga jika kandungan amilopektin meningkat maka semakin banyak pula pasta yang terbentuk dan swelling power juga akan naik,

Jika dibandingkan dengan penelitian Parwiyanti dkk,(2015) yang memodifikasi pati ganyong dengan HMT dan gum xanthan didapatkan nilai swelling power yang meningkat, Dalam kondisi termodifikasi melalui pemanasan suhu tinggi dan pendinginan berulang, granula pati tidak mengalami proses interaksi seperti pada proses gelatinisasi tanpa modifikasi, Hal ini disebabkan karena pati termodifikasi melalui pemanasan dan pendinginan berulang menyebabkan struktur molekul rusak sehingga menghasilkan nilai swelling power yang lebih rendah dibandingkan dengan pati alami (Anonim, 2015), Menurut Wisaniyasa dan Suter (2015), struktur kristalin akan terganggu saat pati dipanaskan dalam jumlah air yang berlebih sehingga terjadi kerusakan ikatan hidrogen dan hidrogen keluar dari kelompok hidroksil amilosa dan amilopektin, Hal ini menyebabkan terjadinya peningkatan nilai swelling power, Semakin lama waktu pemanasan akan menyebabkan granula pati mengembang dan pecah sehingga air yang terdapat dalam granula pati dan molekul pati yang larut air dengan mudah keluar dan masuk ke dalam sistem larutan,

\section{B. Kelarutan}

Menurut Anonim (2016), kelarutan merupakan berat tepung terlarut dan dapat diukur dengan cara mengeringkan dan menimbang sejumlah supernatan, Kelarutan dan swelling power merupakan dua hal yang berkaitan dan terjadi pada saat gelatinisasi, Hasil analisis kelarutan pati ganyong termodifikasi dapat dilihat pada Gambar 2,

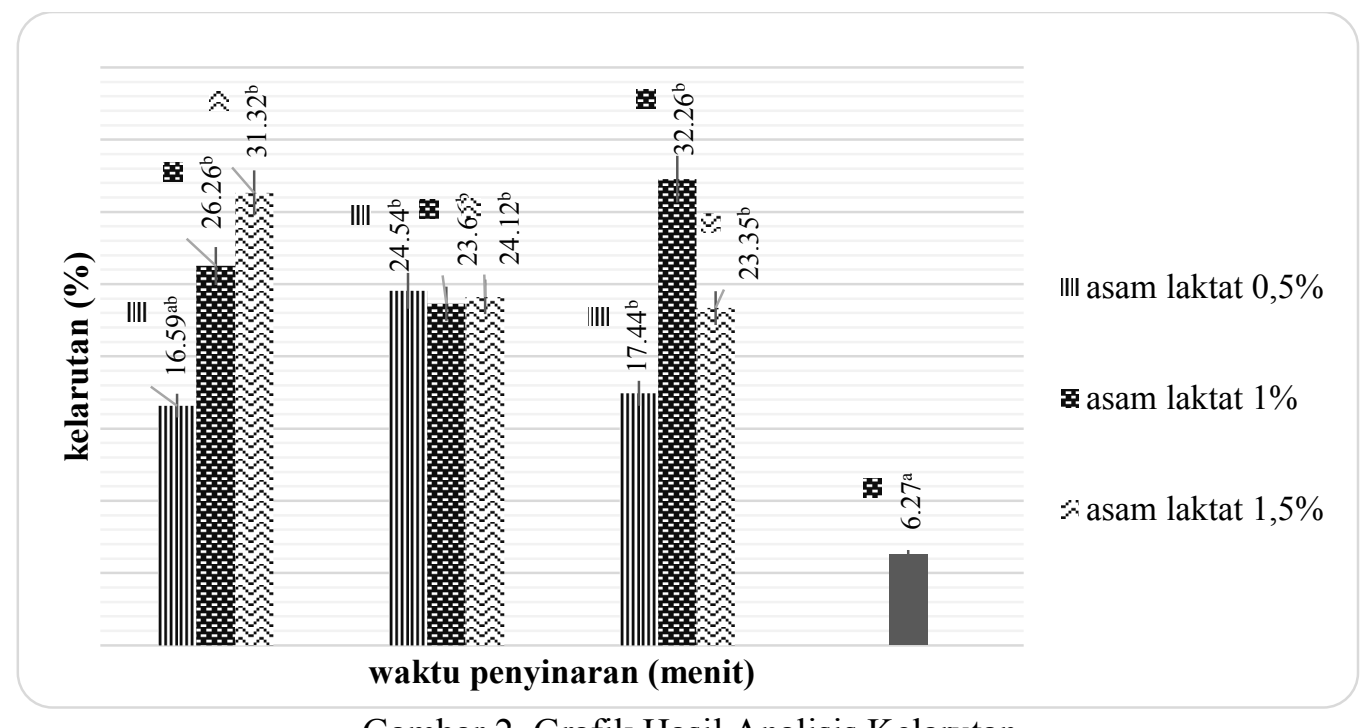

Gambar 2, Grafik Hasil Analisis Kelarutan

Hasil uji statistik pada analisis kelarutan yang dapat dilihat pada Gambar 2, menunjukkan tidak berbeda nyata pada semua perlakuan, Kontrol memiliki hasil yang tidak berbeda nyata dengan perlakuan konsentarsi asam laktat $0,5 \%$ dengan lama oksidasi 5 menit, Pati ganyong termodifikasi cenderung memiliki nilai kelarutan yang lebih besar jika dibandingkan dengan kontrol yang menggunakan pati ganyong tanpa modifikasi, Hal ini karena hidrolisis dengan asam laktat meningkatkan kelarutan pati di dalam air karena proses tersebut merusak struktur menjadi lebih sederhana dan lebih hidrofilik, Penggantian gugus hidroksil oleh gugus yang lebih non-polar menurunkan gaya kohesif antara molekul yang menyebabkan perbaikan sifat alir pati, Penambahan asam laktat yang dilakukan pada penelitian ini akan menurunkan nilai $\mathrm{pH}$ sehingga akan mengakibatkan ukuran molekul pati menjadi lebih kecil sehingga pati akan mudah larut dalam air, 
Menurut Dewi dkk (2012), peningkatan kelarutan diduga karena pati telah terhidrolisis oleh asam sehingga mengakibatkan ukuran molekul pati yang lebih kecil, Dengan ukuran molekul yang lebih kecil tersebut maka mudah untuk larut dalam air,Semakin rendah panjang polimer rantai pati maka semakin tinggi kelarutannya, Molekul amilosa mudah terpecah dibandingkan dengan molekul amilopektin sehingga saat hidrolisis asam berlangsung akan menurunkan gugus amilosa, Dengan semakin mudahnya air yang masuk maka kecenderungan untuk membentuk ikatan hidrogen antara pati dengan molekul air lebih besar,Ikatan hidrogen inilah yang menahan air untuk keluar dari granula pati sehingga pati tersebut dapat larut,

Salah satu faktor yang mempengaruhi kelarutan adalah derajat polimerisasi,Semakin tinggi derajat polimerisasi maka kelarutannya semakin rendah,Sebaliknya jika derajat polimerisasi semakin rendah maka kelarutannya semakin tinggi,Ukuran molekul pati menyebabkan kelarutan meningkat (Pomeranz, 1991), Berdasarkan hasil yang didapat penelitian ini nilai kelarutan pati ganyong termodifikasi yang tinggi menunjukkan bahwa derajat polimerisasinya rendah,

Penelitian yang dilakukan Purnamasari dan Januarti (2010), menunjukkan bahwa kelarutan terkait dengan kemudahan molekul air untuk berinteraksi dengan molekul dalam granula pati dan menggantikan interaksi hidrogen antar molekul sehingga granula akan lebih mudah menyerap air dan mempunyai pengembangan yang tinggi, Adanya pengembangan tersebut akan menekan granula dari dalam sehingga granula akan pecah dan molekul pati terutama amilosa akan keluar,

Kelarutan menunjukkan indikasi tingkat kemudahan suatu tepung untuk dapat larut dalam air, Kelarutanyang tinggi mengindikasikan bahwa tepung lebih mudah larut dalam air dan sebaliknya, Menurut Janathan (2007), hal ini disebabkan partikel-partikel yang tidak larut dalam air akan lebih sedikit yang didispersikan, Semakin tinggi kelarutan maka semakin bagus kualitas tepung tersebut,

Jika dibandingkan nilai kelarutan pati ganyong yang telah dimodifikasi menggunakan asam laktat dan lampu UV-C dengan penelitian Parwiyanti dkk, (2015), yang memodifikasi pati ganyong menggunakan HMT dan gum xanthan memiliki nilai kelarutan yang lebih rendah atau menurun seiring bertambahnya konsentrasi gum xanthan dan lama waktu HMT, Menurut Gomes dkk, (2005), kelarutan adalah akibat dari larutnya amilosa, Penurunan nilai kelarutan saat gelatinisasi menunjukkan meningkatnya interaksi antara molekul amilosa dan amilopektin membentuk struktur stabil sehingga menghambat amilosa untuk menghilang dari granula pati,

\section{Volume Pengembangan}

Volume pengembangan merupakan nilai perbandingan antara volume spesifik dengan berat adonan panggang,Proses hidrolisis pati dengan asam laktat dan penyinaran lampu UV-C dilakukan pada konsentrasi asam laktat $0,5 \%$; $1 \%$; dan 1,5\%, lama penyinaran dengan lampu UV-C 5 menit; 10 menit; dan 15 menit kemudian hasil pati terhidrolisis dikeringkan didalam cabinet dryer dengan suhu $50^{\circ} \mathrm{C}$ selama 1 jam, Masing-masing perlakuan tersebut kemudian dianalisis volume pengembangannya,Nilai volume pengembangan dapat dilihat pada Gambar 3,

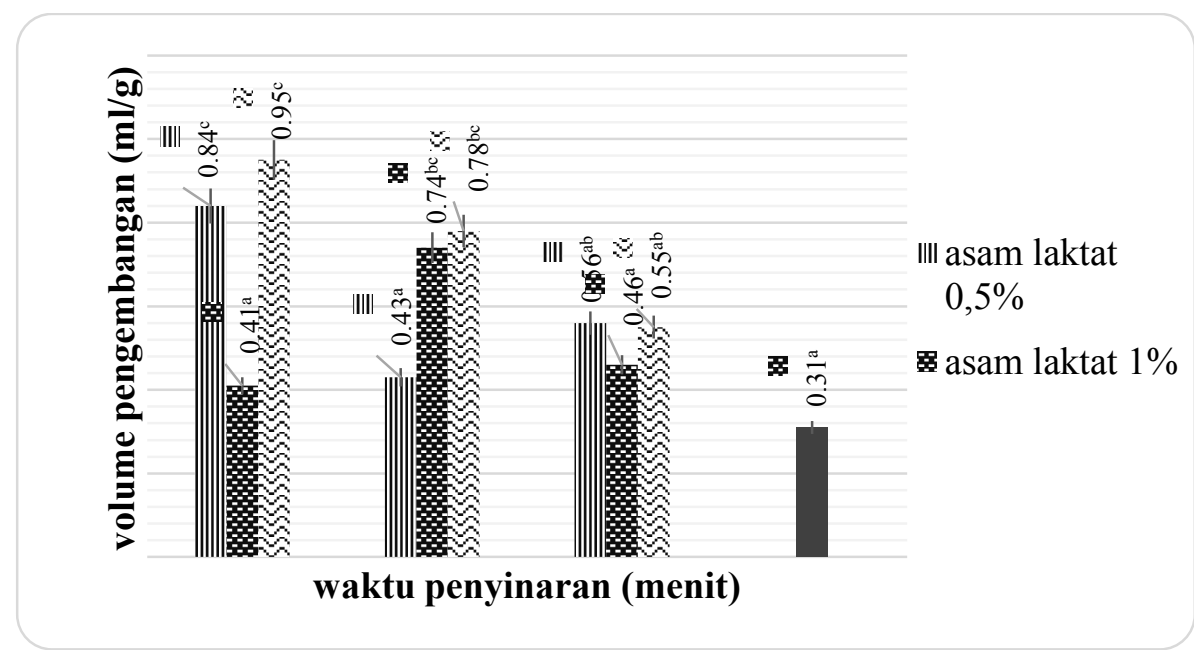

Gambar 3,Grafik Hasil Analisis Volume Pengembangan 
Hasil uji statistik pada analisis volume pengembangan dapat dilihat pada Gambar 3,volume pengembangan dari hasil penelitian yang telah dilakukan pada konsentrasi $0,5 \%$ dan $1,5 \%$ asam laktat yang menggunakan lama oksidasi 5 menit didapatkan hasil yang tidak berbeda nyata, Pada konsentrasi $1 \%$ dan 1,5\% asam laktat yang menggunakan lama oksidasi 10 menit juga didapatkan hasil yang tidak berbeda nyata, Sedangkan lama oksidasi 15 menit dengan konsentrasi asam laktat $0,5 \%$ dan $1,5 \%$ didapatkan hasil yang tidak berbeda nyata, Jika dibandingkan dengan kontrol yang menggunakan pati ganyong tanpa modifikasi, hasil yang didapatkan pada pati ganyong yang telah dimodifikasi memiliki nilai volume pengembangan lebih besar walaupun hasil yang didapat belum menunjukkan hasil yang stabil, Hal ini dikarenakan kemampuan granula pati untuk menyerap air dan amilopektin sudah maksimum ,karena amilopektin memiliki sifat cenderung tidak larut air, apabila kandungan amilopektin tidak meningkat maka pasta yang terbentuk dan volume pengembangannya juga mulai stabil,

Penelitian ini telah sesuai dengan penelitian Pudjihastuti (2010), yang melakukan penelitian pada tapioka menggunakan modifikasi hidrolisis asam laktat dan penyinaran lampu UV-C, menunjukkan hasil nilai volume spesifik yang meningkat,Sedangkan penelitian yang dilakukan Muflihati dkk,(2018), dengan memodifikasi pati ganyong menggunakan iradiasi UV-C dan mengolahnya menjadi roti menghasilkan tingkat baking expansion yang meningkat, Hal ini menunjukkan bahwa modifikasi menggunakan sinar UV-C dapat meningkatkan nilai volume pengembangan pada pati,Sama halnya dengan penelitian Bertolini dkk,(2000), yang melakukan modifikasi pati singkong dan jagung yang diolah menjadi roti menunjukkan nilai volume pengembangan yang semakin meningkat seiring semakin lama waktu penyinaran menggunakan lampu UV dan bertambahnya konsentrasi asam,

Menurut Wang dan Wang (2003), volume pengembangan mengalami kenaikan karena berhubungan dengan pembentukan gugus karbonil dan karboksil selama oksidasi,Sedangkan menurut Demiate dkk,(2000), gugus karboksil yang ada akan memberikan daya pengembangan yang besar, Hal ini akan menyebabkan kenaikan kemampuan masuknya air (hidrasi) dari molekul pati yang teroksidasi, Asam yang terserap oleh granula pati akan menyebakan terjadinya degradasi granula pati menjadi molekul - molekul yang lebih kecil dan mudah larut dalam air, Semakin lama pati ganyong yang dimodifikasi dengan asam laktat dan sinar UV maka akan menhasilkan volume pengembangan yang cukup tinggi (Demiate dkk,, 2000),

Berbeda dengan penelitian yang dilakukan oleh Sumardiono dan Pudjihastuti (2010), pada modifikasi pati singkong dengan hidrolisis asam laktat dan UV menunjukkan semakin bertambah konsentrasi asam laktat nilai volume pengembangannya semakin menurun sedangkan semakin lama waktu penyinaran dengan UV nilai volume pengembangan yang awalnya meningkat kemudian menurun dan menjadi stabil, Hal ini disebabkan karena pengaruh sinar UV terhadap volume pengembangan ini menyebabkan asam yang berdifusi kedalam granula pati akan mendorong terjadinya degradasi granula pati menjadi molekul molekul yang lebih kecil dan mudah larut dalam air,

Menurut Tavares dkk,(2010), oksidasi pati sebagian besar menyebabkan pemotongan ikatan glikosidik dan mengoksidasi gugus hidroksil menjadi gugus karbonil dan karboksil,Pemotongan ikatan glikosidik mengakibatkan depolimerisasi amilosa dan amilopektin sehingga menyebabkan penurunan viskositas pasta, Akibatnya ikatan antar molekul juga akan rendah, sehingga pengikatan air akan lebih mudah, Hal ini yang dapat menghasilkan adonan bisa mengembang besar selama pemanggangan,

Peningkatkan nilai volume pengembanganpati ganyong teroksidasi disebabkan karena proses oksidasi pati menyebabkan jumlah air yang terikat dalam pati semakin banyak, sehingga uap air selama proses baking makin banyak pula dan pengembangan produk menjadi semakin besar (Bertolini dkk,, 2001), Sementara penurunan volume pengembangan pada pati ganyong yangtinggi disebabkan karena fotooksidasi berlebih menyebabkan degradasi pati pada dinding bahan terlalu ekstensif sehingga kehilangan integritasnya lebih awal dan tidak terjadi pengembangan (Vatanasuchart dkk,, 2005), Selain itu, dengan suhu gelatinisasi yang lebih tinggi akan menurunkan tingkat pembengkakan pati dan bisa menunda adonan mengalami peningkatan volume pengembangan (Bertolini $\mathrm{dkk}, 2000)$, 
Menurut Dias dkk,(2011 a), asam laktat dikatakan dapat membantu peningkatan oksidasi dan mendepolimerisasi pati yang mengakibatkan penurunan viskositas, Ikatan antar molekul bisa merenggang karena adanya penambahan asam laktat sehingga air dapat masuk kedalam molekul pati sehingga volume pengembangan akan meningkat selama proses pemanggangan, Namun keberadaan asam laktat secara berlebih akan menyebabkan ikatan ikatan antar molekul dalam granula pati akan terlalu renggang sehingga tidak mampu memerangkap air yang masuk dan mengakibatkan penurunan volume pengembangan pada saat pemanggangan,

Menurut penelitian Anindya dan Haryadi (2014), nilai baking expansion yang tinggi tidak ditunjukkan dengan tingginya pembentukan gugus karbonil dan karboksil,Hal ini disebabkan kesetimbangan antara jumlah gugus karbonil dan karboksil yang dibutuhkan untuk mendapatkan tingkat pengembangan sudah maksimal,Penelitian yang dilakukan Pudjihastuti (2010), pada tapioka yang dimodifikasi dengan sinar UV dan hidrolisis asam laktat menunjukkan semakin bertambahnya konsentrasi asam laktat nilai volume pengembangannya semakin menurun karena adanya gugus amilosa yang terbentuk sehingga cenderung larut dalam air dan menyebabkan berkurangnya pasta yang terbentuk, sedangkan semakin lama waktu penyinaran dengan UV nilai volume pengembangan cenderung stabil,

\section{Warna}

Warna merupakan salah satu atribut penampilan pada suatu produk yang seringkali menentukan tingkat penerimaan konsumen terhadap produk tersebut secara keseluruhan, Hasil pengujian warna yang meliputi kecerahan $(\mathrm{L})$, nilai a dan $b$ pada pati ganyong termodifikasi dapat dilihat pada Tabel 1,

Tabel 1. Data Hasil Analisis Warna

\begin{tabular}{|c|c|c|c|c|c|c|c|c|c|}
\hline \multirow{3}{*}{$\begin{array}{c}\text { Lama } \\
\text { oksidasi } \\
\text { (menit) }\end{array}$} & \multicolumn{9}{|c|}{ Konsentrasi Asam Laktat (\%) } \\
\hline & \multicolumn{3}{|c|}{0,5} & \multicolumn{3}{|c|}{1} & \multicolumn{3}{|c|}{1,5} \\
\hline & $\mathrm{L}$ & $\mathrm{a}$ & $\mathrm{b}$ & $\mathrm{L}$ & $\mathrm{a}$ & $\mathrm{b}$ & $\mathrm{L}$ & $\mathrm{a}$ & $\mathrm{b}$ \\
\hline 5 & $76^{\mathrm{a}}$ & $-16^{a}$ & $15,33^{\mathrm{ab}}$ & $76^{\mathrm{a}}$ & $-17^{\mathrm{a}}$ & $17,67^{\mathrm{ab}}$ & $76^{\mathrm{a}}$ & $-15,33^{a}$ & $16,67^{\mathrm{ab}}$ \\
\hline 10 & $76,67^{\mathrm{a}}$ & $-16,33^{\mathrm{a}}$ & $18^{\mathrm{b}}$ & $76^{\mathrm{a}}$ & $-16,67^{a}$ & $18^{\mathrm{b}}$ & $75,67^{\mathrm{a}}$ & $-16,67^{a}$ & $17,67^{\mathrm{ab}}$ \\
\hline 15 & $75,67^{\mathrm{a}}$ & $-17^{a}$ & $17,67^{\mathrm{ab}}$ & $75,67^{\mathrm{a}}$ & $-15^{a}$ & $16^{\mathrm{ab}}$ & $76^{a}$ & $-16^{a}$ & $17,67^{\mathrm{ab}}$ \\
\hline Kontrol & $76,67^{\mathrm{a}}$ & $-16^{\mathrm{a}}$ & $15^{\mathrm{a}}$ & & & & & & \\
\hline \multicolumn{10}{|c|}{$\begin{array}{l}\text { Keterangan : } \\
\text { - Angka merupakan rata-rata } 3 \text { kali ulangan } \pm \text { standar deviasi } \\
\text { - Huruf notasi yang berbeda menunjukkan adanya beda nyata pada taraf signifikansi }(\alpha) 5 \% \\
\text { - Kontrol menggunakan pati ganyong tanpa modifikasi } \\
\text { - L (derajat keputihan/kecerahan) dengan nilai } 0=\text { hitam dan } 100=\text { putih, a (nilai positif berarti derajat } \\
\text { kemerahan dan nilai negatif berarti derajat kehijauan), dan b (nilai positif berarti derajat kekuningan dan } \\
\text { negaif berarti kebiruan), }\end{array}$} \\
\hline
\end{tabular}

Hasil uji statistik pada analisis warna yang dapat dilihat pada Tabel 1, menunjukkan bahwa nilai $\mathrm{L}$, a, dan $\mathrm{b}$ pada semua perlakuan memiliki hasil yang tidak berbeda nyata, Tingkat kecerahan (L) pada semua perlakuan bernilai positif berkisar 75-76 yang menunjukkan pati ganyong modifikasi berwarna menuju putih, Pada perlakuan lama penyinaran 10 menit tingkat kecerahan pati ganyong menurun seiring bertambahnya konsentrasi asam laktat, Sedangkan tingkat kemerahan (a) pada pati ganyong yang dimodifikasi dengan sinar UV-C dan hidrolisis asam laktat menunjukkan nilai negatif berkisar -15 sampai -17 yang berarti menunjukkan warna menuju hijau, Untuk tingkat kekuningan (b) pada pati ganyong yang telah dimodifikasi pada semua perlakuan menunjukkan nilai positif berkisar antara 15-18 yang menunjukkan warna pati ganyong modifikasi menuju warna kuning, Jika dibandingkan dengan kontrol, warna pati ganyong yang telah dimodifikasi tidak menunjukkan perbedaan secara signifikan, Tetapi asam laktat yang ditambahkan pada pati ganyong akan menyebabkan pati ganyong tingkat kecerahannya berkurang menjadi semakin kekuningan,

Menurut Palupi (2011), jika fotoreaksi terjadi maka akan menginduksi terjadinya transfer elektron dan juga akan menyebabkan proses oksidasi pada senyawa polimer sehingga menghasilkan produk berwana kuning, Oleh karena itu penurunan tingkat kecerahan pada pati ganyong dikarenakan 
produk mengalami kekuningan,Menurut Rivera dkk,(2005), reaksi oksidasi yang terjadi menyebabkan sebagian pigmen dan protein teroksidasi terlebih dahulu sebelum glukosa sehingga senyawa yang adasebagian akan hilang dan akan dihasilkan pati yang lebih putih, lebih intensif dalam pengurangan intensitas warna kuning pada tepung,

\section{E. Nilai pH}

Nilai $\mathrm{pH}$ atau derajat keasaman digunakan untuk menyatakan tingkat keasaman atau basa yang dimiliki oleh suatu zat, larutan atau benda, $\mathrm{pH}$ normal memiliki nilai 7 sementara bila nilai $\mathrm{pH}>$ 7 menunjukkan zat tersebut memiliki sifat basa sedangkan nilai $\mathrm{pH}<7$ menunjukkan keasaman, $\mathrm{pH} 0$ menunjukkan derajat keasaman yang tinggi, dan $\mathrm{pH} 14$ menunjukkan derajat kebasaan tertinggi,

Proses hidrolisis asam laktat dan sinar UV-C dilakukan pada konsentrasi asam laktat $0,5 \%$; 1\%; dan 1,5\% dengan penyinaran lampu UV-C 20 watt selama 5 menit; 10 menit; dan 15 menit, kemudian dianalisis nilai $\mathrm{pH}$, Data nilai $\mathrm{pH}$ dapat dilihat pada Gambar 4,

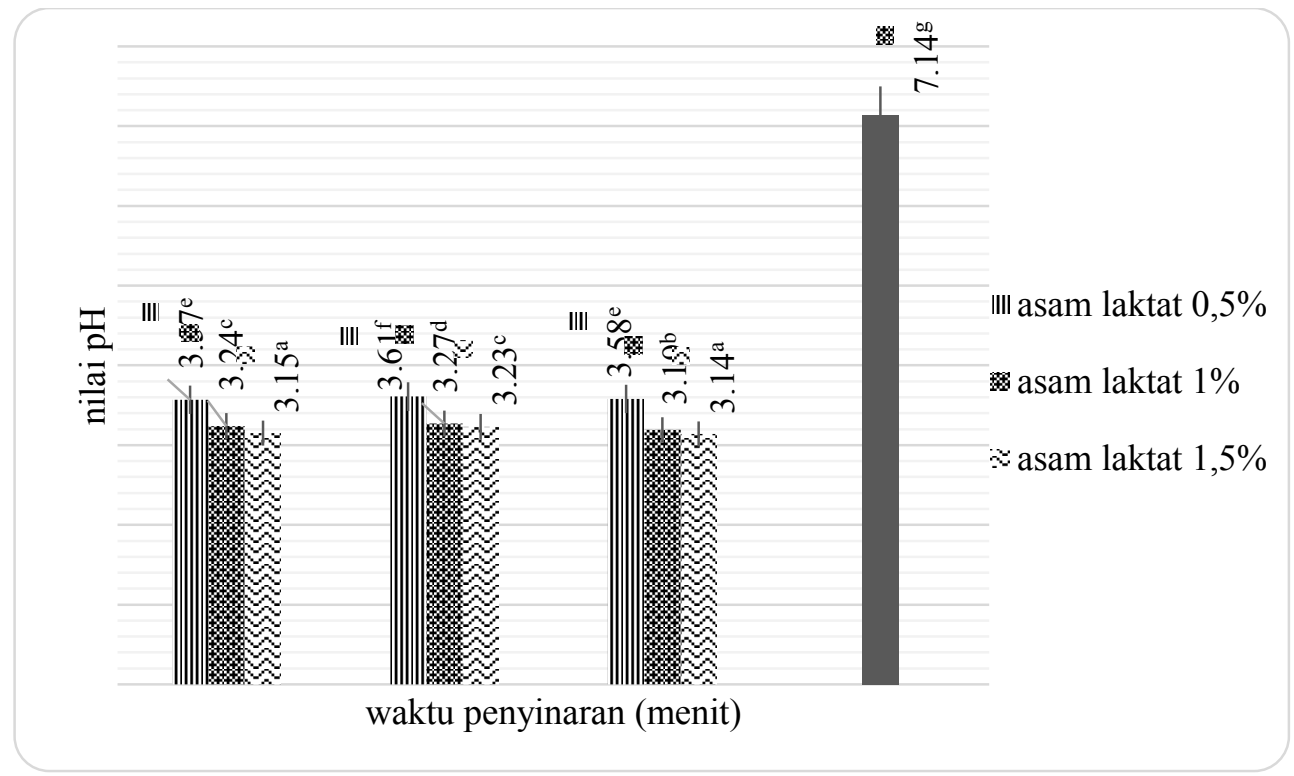

Gambar 4, Grafik Hasil Analisis pH

Hasil uji statistik pada analisis $\mathrm{pH}$ yang dapat dilihat pada Gambar 4,Nilai $\mathrm{pH}$ yang didapat pada perlakukan lama oksidasi 5 menit dan 15 menit dengan konsentrasi asam laktat 1,5\% didapatkan hasil yang tidak berbeda nyata, Pada lama oksidasi 5 menit dan 15 menit dengan konsentrasi asam laktat $0,5 \%$, konsentrasi asam laktat $1 \%$ dengan lama oksidasi 5 menit, lama oksidasi 10 menit dan konsentrasi asan laktat $1,5 \%$ didapatkan hasil yang tidak berbeda nyata, Sedangkan perlakuan yang lain menunjukkan hasil yang berbeda nyata, Semakin bertambahnya konsentrasi asam laktat yang ditambahkan pada pati ganyong maka nilai $\mathrm{pH}$ yang didapatkan juga semakin rendah atau semakin asam,Sedangkan pada kontrol yang menggunakan $100 \%$ pati ganyong tanpa perlakuan didapatkan nilai $\mathrm{pH}$ yang mendekati netral,Sehingga pati ganyong termodifikasi memiliki nilai $\mathrm{pH}$ yang rendah jika dibandingkan dengan kontrol,Nilai $\mathrm{pH}$ yang semakin rendah karena penambahan konsentrasi asam laktat yang semakin tinggi sehingga tingkat keasaman pati juga tinggi dan memiliki nilai $\mathrm{pH}$ yang rendah,

Menurut Kesselmans dkk, (2004), semakin tinggi konsentrasi asam laktat maka nilai pH semakin rendah,Pengaruh $\mathrm{pH}$ pada pati terdapat pada penambahan gugus karbonil $(\mathrm{C}-\mathrm{O})$ dan gugus karboksil (C-O-O-H), Gugus karbonil dan karboksil tersebut sangat berpengaruh pada viskositas pasta yang terbentuk, karena sangat berpengaruh pada proses degradasi amilosa, Semakin meningkatnya degradasi amilosa maka pasta yang terbentuk juga akan semakin sedikit dan akan menurunkan nilai volume pengembangannya,

Penurunan nilai $\mathrm{pH}$ pada pati ganyong termodifikasi akan mempengaruhi nilai swelling power, kelarutan, volume pengembangan, dan warna, Nilai $\mathrm{pH}$ yang rendah akan menurunkan nilai 
swelling power karena akan terjadi gelatinisasi parsial pada pati, Gelatinisasi merupakan proses pembengkakan granula dalam pati, Pembengkakan granula lebih lanjut, menyebabkan dindingdinding granula mulai terpecah dan rusak, sehingga dapat menurunkan nilai swelling power (Vatanasuchart dkk,,2005), Sedangkan nilai kelarutan pati ganyong termodifikasiakan semakin meningkat seiring menurunnya nilai $\mathrm{pH}$, Menurut Zulaidah (2012), substitusi gugus asetil pada tepung gadung dapat melemahkan ikatan hidrogen pada molekul pati sehingga air menjadi lebih mudah berpenetrasi ke dalam granula pati dan menyebabkan keluarnya amilosa dari granula, sehingga nilai kelarutanpada pati modifikasi meningkat daripada pati alaminya,

Menurut penelitian Sari dkk, (2012), pada konsentrasi asam laktat 1\% dengan pH 8 dan 5 didapatkan jumlah gugus karboksil dan karbonil tertinggi pada nilai $\mathrm{pH}$ 5,Hal ini menujukan semakin asam maka semakin bagus untuk modifikasi pati karena pada kondisi basa dapat mengurangi volume pengembangan, Sesuai penelitian Bertolini dkk,(2000), yang melakukan modifikasi pati singkong menggunakan hidrolisis asam laktat dan iradiasi sinar UV menyatakan bahwa modifikasi tersebut dapat mengubah kandungan amilosa sehingga mempengaruhi sifat rheologi tapioka seperti menurunnya viskositas pasta dari tapioka,Selain dapat menurunkan viskositas, radiasi UV pada tapioka juga meningkatkan keasaman dan meningkatkan volume adonan pati selama pemanggangan,

\section{KESIMPULAN}

1. Asam laktat yang digunakan dalam modifikasi pati ganyong menurunkan nilai swelling power, meningkatkan kelarutan, meningkatkan volume pengembangan, mengurangi tingkat kecerahan dan meningkatkan tingkat kekuningan, serta menurunkan nilai $\mathrm{pH}$ pati ganyong,

2. Modifikasi menggunakan penyinaran lampu UV-C pada pati ganyong menghasilkan nilai swelling power yang menurun tetapi kelarutannya meningkat, volume pengembangan juga meningkat, tetapi mengurangi tingkat kecerahan dan meningkatkan tingkat kekuningan, serta menurunkan nilai $\mathrm{pH}$ pati ganyong.

\section{DAFTAR PUSTAKA}

Anonim. 2015. Pembuatan Pati. http://www. analisispangan. c om/2015/12/pembuatan-pati-ubi-jalar. html. Diakses pada tanggal 12 Mei 2018

Anonim. 2016. Sifat Fungsional. http://www. analisispangan. com/2016/08/sifat-fungsional-selesai. html. Diakses pada tanggal 20 Mei 2018

An. H. Y. 2005. Effects of Ozonation and Addition of Amino acids on Properties of Rice Starches. A Dissertation Submitted to the Graduate Faculty of the Louisiana State University and Agricultural and Mechanical College.

Anindya. A. S, dan Haryadi. Oksidasi Hancuran Singkong Menggunakan $\mathrm{H}_{2} \mathrm{O}_{2}$ dan Asam Laktat dengan Katalisator Ferrous Sulfate Heptahydrate untuk Meningkatkan Baking Expansion. Jurnal Aplikasi Teknologi Pangan 3 (4).

AOAC. 1990.Official Methods of Analysis. Association of Official Analytical Chemist. Washington.

Bertolini. A. C., Christian, Mestres, dan Paul. C. 2000. Rheological Properties Of Acidified and UVIrradiated Starches. Starch/Stärke $52: 340-344$.

Bertolini. A. C., Christian M., Denis L., Guy D., dan Paul C. 2001. Relationship Between Thermomechanical Properties and Baking Expansion Of Sour Cassava Starch (Polvilho Azedo). Sci Food Agric 81:429-435.

Costa. F. J. O. G., Almeida. R. R., Lacerda. L. G., Carvalho. F. M. A. S., Bannach. G, dan Schnitzler. E. 2011. Thermoanalytical Study Of Native Cassava Starch and Treated With Hydrogen Peroxide. Alim Nutr Araraquara 22 (1) : 7-1.

Demiate. I. M., Gilvan W., Marney. P. C., dan Christian. M. 2000. Relationship Between Baking Behavior Of Modified Cassava Starches and Starch Chemical Structure Determined By FTIR Spectroscopy. Journal Of Carbohydrate Polymers 42:149-158. 
Dewi. N. S., Parnanto. N. H. R., dan Achmad. R. A. 2012.Karakteristik Sifat Fisikokimia Tepung Bengkuang (Pachyrhizuserosus) Dimodifikasi secara Asetilasi dengan Variasi Konsentrasi Asam Asetat Selama Perendaman. Jurnal Teknologi Hasil Pertanian 5 (2): 104-112.

Dias. A. R. G., Elessandra. R. Z., Helbig. F. A. M., Vargas.C. G., danCiacco. C. F. 2011 a . Oxidation of Fermented Cassava Starch Using Hydrogen Peroxide. Carbohydrate Polymer 86:185-191.

Dias. A. R. G., Elessandra. R. Z., Elessandra R. Z., Moacir. C. E., Elizabete. H., Debora. O. S., dan Cesae. F. C. 2011 b. Pasting. Expansion. and Textural Properties Of Fermented Cassava Starch Oxidised With Sodium Hypochlorite. Journal Carbohydrate Polymers 84: 268-27.

Gomes. A. M. M. 2005. Effects Of Annealing On The Physicochemical Properties Of Fermented Cassava Starch (Polvilho Azedo). Journal Carbohydrate Polymers $60: 1-6$.

Lutfika. E. 2006. Evaluasi Mutu Gizi dan Indeks Glikemik Produk Olahan Panggang Berbahan Dasar Tepung Ubi Jalar (Ipomoea batatas L.) Klon Unggul BB00105.10.Skripsi. Institut PertanianBogor.

Janathan. 2007. Karakteristik Fisikokimia Tepung Bekatul Serta Optimasi Formula Dan Pendugaan Umur Simpan Minuman Campuran Susu Skim Dan Tepung Bekatul. Skripsi.Fakultas Teknologi Pertanian Institut Pertanian Bogor. Bogor.

Kainuma. K., Odat T., dan Cuzuki S. 1967. Study of Starch Phosphate Monoeters. Journal Technocol. Soc. Starch 14:24-28.

Kesselmans. A., Ido. P. B., dan Ten. B. 2004. Oxidation of Starch. United States Patent no 6. 777. 548. B1

Koswara. S. 2009. Teknologi Modifikasi Pati. SEAFAST Center. Research and Community Service Institution Bogor Agricultural University.

Koswara. S. 2014. Teknologi Pengolahan Umbi-Umbian. Fakultas Teknologi Pertanian. Institut Pertanian Bogor. Bogor.

Muflihati, I. 2018. Sifat Fisikokimia dan Sensoris Roti Hasil Subtitusi Pati Ganyong yang Dimodifikasi Melalui Iradiasi Sinar UV-C. Jurnal Ilmiah Teknosains 4 (1) : 11-15.

Muflihati. I., Lukitawesa., Narindri, B., Afriyanti., Mailia, R. 2015. Efek Substitusi Tepung Terigu Dengan Pati Ketan Terhadap Sifat Fisik Cookies. Seminar Nasional Universitas PGRI Yogyakarta.

Palupi, N. W,. 2011.Pengaruh Konsentrasi Hidrogen Peroksida dan Lama Penyinaran UV-C Terhadap Tingkat Oksidasi dan Pengembangan Pati Cassava pada Proses Pengembangan. Thesis. Fakultas Teknologi Pertanian. Universitas Gadjah Mada. Yogyakarta.

Parwiyanti. F. P., Wijaya. A., .Malahyati N., dan Liadiasari. E. 2015. Swelling Power dan Kelarutan Pati Ganyong (Canna Edulis Kerr. )Termodifikasi Melalui Heat-Moisture Treatment dan Penambahan Gum Xanthan untuk Produk Roti. Prosiding Seminar Hasil Penelitian Tanaman Aneka Kacang dan Umbi. Fakultas Pertanian Universitas Sriwijaya.

Pomeranz. Y. 1991.Functional Properties of Food Components.Second Edition.AcademicPress. Inc.

Pudjihastuti. I. 2010.Pengembangan Proses Inovatif Kombinasi Reaksi Hidrolisis Asam dan Reaksi Photokimia UV untuk Produksi Pati Termodifikasi dari Tapioka. Tesis. Program Pascasarjana. Universitas Diponegoro : Semarang

Purnamasari. I dan Januarti. H. 2010. Pengaruh Hidrolisa Asam Alkohol dan Waktu Hidrolisa Terhadap Sifat Tepung Tapioka. Jurusan TeknikKimia. Fakultas Teknik. Universitas Diponegoro.

Rivera. M. M. S., F. J. L. Garcia S., M. V. del Valle., F. G. Meraz., dan L. A. Bello P. 2005.Partial Characterization of Banana Starches Oxidized by Different Levels of Sodium Hypochlrite. Carbohydrate Polymer 62: 50-56.

Sari. D. P. , Siregar. D. M, dan Sumardiono. S. 2012.Modifikasi Tapioka dengan Kombinasi Proses Hidrolisa Asam Laktat dan Oksidasi Hidrogen Peroksida untuk Meningkatkan Daya Kembang. Jurnal Teknologi Kimia dan Industri 1 (1) : 86-91

Setya. A. 2015.Iradiasi Sinar UV-C pada Hancuran Singkong Dalam Larutan Asam Laktat Hidrogen Peroksida untuk Mendapatkan Tepung dengan Baking Expansion yang Meningkat. Jurnal Aplikasi Teknologi Pangan 4 (1) 
Sumardiono. S., dan Pudjihastuti. I. 2015.Pengembangan Proses Modifikasi Cassava dengan Hidrolisa Asam Laktat dan UV untuk Substitusi Terigu dalam Produk Pangan. Jurnal Metana. 11 (2): 27 $-32$

Tavares. A. C. K. , Zanatta. E., Zavareze. E. R., Helbig. E., dan Dias. A. R. G. 2010.The Effect of Acid and Oxidative Modification on The Expansion Properties of Rice Flours with Varying Levels of Amylose. LWT-Food Science And Technology. 43 : 1213-1219.

Teja. W., Albert. I. S. P., Aning. A., dan Laurentia. E. K. S. 2008. Karakteristik Pati Sagu dengan Metode Modifikasi Asetilasi dan Cross Linking. Jurnal Teknik Kimia Indonesia 7(3) : 836-843.

Vatanasuchart. N. O., Naivikul., Charoenrein. S., dan Sriroth. K. 2005. Molecular Properties Of Cassava Starch Modified with Different UV Irradiations to Enhance Baking Expansion. Carbohydrate Polymers $61: 80-87$

Wang. Y. J., dan Wang. L. 2003. Physicochemical Properties of Common and Waxy Corn Starch Oxidized by Different Level of Sodium Hypochlorite. Carbohydrate Polymers 52: 207-217.

Watcharatewinkul. Y., Puttanlek. C., Rungsardthong. V., dan Uttapap. D. 2009. Pasting Properties Of Heat-Moisture Treated Canna Starch In Relation To Its Structural Characteristics. Carbohydrate Polymers 75(3):505-511.

Wisaniyasa. N. M. dan Suter. I. K. 2015. Kajian Sifat Fungsional dan KimiaTepung Kecambah Kacang Merah (Phaseolus Vulgarisl. ) danAplikasinya Menjadi Flakes. Laporan Akhir Hibah Unggulan Program Studi (Hups). Fakultas Teknologi Pertanian. Universitas Udayana. Bali

Zulaidah. A. 2012. Peningkatan Nilai Guna Pati Alami melalui Proses Modifikasi Pati. Jurnal Dinamika Sains $10(22): 1-13$ 